\title{
Assessment of Algerian Maize Populations for Saccharification and Nutritive Value
}

\author{
Ana López-Malvar 1,2 (D), Abderahmane Djemel ${ }^{3}$, Leonardo Gomez ${ }^{4}$, Rogelio Santiago ${ }^{1,2}$ and \\ Pedro Revilla 5 ,*iD \\ 1 Department of Plant Biology and Soil Science, University of Vigo, Campus as Lagoas-Marcosende, \\ 36310 Vigo, Spain; alopezmalvar@uvigo.es (A.L.-M.); rsantiago@uvigo.es (R.S.) \\ 2 Agrobiología Ambiental, Calidad de Suelos y Plantas (Universidad de Vigo), Unidad Asociada a la Misión \\ Biológica de Galicia (CSIC), Apartado 28, 36080 Pontevedra, Spain \\ 3 École Nationale Supérieure Agronomique, El Harrach, Avenue Hassan Badi, Alger 16200, Algeria; \\ djemeldahmane@yahoo.fr \\ 4 Department of Biology, Centre for Novel Agricultural Products University of York Wentworth Way, \\ York YO10 5DD, UK; leonardo.gomez@york.ac.uk \\ 5 Misión Biológica de Galicia (CSIC), Apartado 28, 36080 Pontevedra, Spain \\ * Correspondence: previlla@mbg.csic.es; Tel.: +34-986-85-48-00
}

Received: 6 April 2020; Accepted: 28 April 2020; Published: 2 May 2020

\begin{abstract}
Maize (Zea mays L.) from the Algerian Sahara was adapted to arid conditions and has been used for food and feed. The objective of this work was to assess the potential value of Saharan maize for saccharification and nutritive value under drought conditions. Eighteen maize populations from the Algerian Sahara were evaluated under drought and control conditions and representative samples of those populations were taken for nutrients and saccharification analyses. The evaluation of saccharification was made in one Spanish trial under drought and control conditions. Differences among Algerian populations for nutritive value were significant for starch and ash, but not for lipids and proteins. Drought-reduced saccharification yield and differences among populations were significant for saccharification potential under drought conditions, and for saccharification yield under both drought and control conditions. The Algerian populations PI527465 and PI542689 had high grain starch and low ash, PI527469 and PI527474 had a balanced nutritional value, and PI527475 and PI542683 had low grain starch and moderately high ash. Besides high nutritional value, the drought-tolerant population PI542683 had high saccharification under drought conditions. Most agronomic traits had no significant effects on saccharification, and some grain nutrients affected saccharification and agronomic performance. Therefore, improving the nutritive value of grain and saccharification of stover, while maintaining agronomic performance, could be feasible, attending to the weak interactions between them.
\end{abstract}

Keywords: Zea mays L.; nutrients; saccharification; Algerian landraces

\section{Introduction}

Maize (Zea mays L.) has been used mainly for feed and secondarily for food and as a source of biomass for renewable energy [1]. As the average harvest index of maize is 0.5 , half of the biomass can be used for nutrition and half for bioenergy under standard conditions, but some factors, such as stresses, can alter the potential value of maize for diverse uses [1].

Drought is the main stress for maize worldwide [2,3]. Consequently, drought tolerance should be a major objective of breeding programs. Sources of drought tolerance have been reported in tropical environments [3] and we have identified semitropical Algerian maize populations from the Sahara as 
potential sources of drought tolerance for temperate environments [4-6]. However, the adaptation of photoperiod-sensitive varieties from lower latitudes to temperate areas is another limiting factor.

Breeding maize for food or feed requires the improvement of the nutrient balance because maize and most cereals have low proportion and deficiencies of proteins and lipids [7]. Maize grain contains about $72 \%$ starch, $10 \%$ protein, and $4 \%$ lipid [ 8 ] and provides about $15 \%$ of the world's protein and $20 \%$ of the world's calories [9]. Starch is the primary carbohydrate of maize, and sugars range from $1 \%$ to $3 \%$ [10]. Ash contains minerals and heavy metals.

Plant sugars, starch, and cellulose can be used for bioethanol production. Cellulosic ethanol derived from fast-growing $\mathrm{C} 4$ grasses has become the preferred alternative, as it is the greatest depository of renewable energy. With the potential to generate a major source of lignocellulosic biomass, maize has been postulated as an outstanding model for studying the complex cell wall network, and also as a model to optimize crop breeding strategies in bioenergy grasses. Maize stover, the residue left after harvesting the grain, is the largest and readily available substrate for lignocellulosic feedstock [11-15]. In this way, double exploitation of the crop could be achieved. The conversion of starch to ethanol is more straightforward than the digestion of lignocellulose as a renewable carbon substrate [12]. However, there is an increasing rejection of the use of food for fuel [16], which has moved the focus from maize grain towards lignocellulosic biomass as a source of bioenergy. Therefore, substituting starch as a substrate for ethanol production by lignocellulose is convenient due to its abundance, low requirements of inputs, low greenhouse gas emissions, and large net energy outputs [17].

Algerian maize germplasm from subtropical areas exhibited high phenotypic and genetic diversity and wide adaptation to temperate regions [4,18]. Moreover, Cherchali et al. [19] identified heterotic patterns between Algerian maize populations and heterotic groups from northern and southern Spain, and with the US Corn-Belt Dent. Based on the reported variability of Algerian maize populations, we decided to assess the potential value of that germplasm for feed and food, and also as a source of biomass for renewable energy under drought conditions. Furthermore, we analyzed if selection for higher nutritive value could affect agronomic performance, and if selection for better agronomic performance could affect the saccharification value. The expected growing area of the potentially improved released varieties includes the Mediterranean area, as the populations were representative of the genetic diversity available in Spain and Algeria and the agronomic evaluations were made in both countries.

\section{Materials and Methods}

Eighteen open-pollinated Algerian maize populations were evaluated along with EPS14(FR)C3, included as a check from the dry Spain, and EPS13(FR)C3, as a check from the humid Spain, under both drought and control conditions, following a randomized complete block design with three replications, in 2016 and 2017 in Algiers and northwestern Spain [20]. Experimental plots were $6 \mathrm{~m}^{2}$ and around 60,000 plants $\mathrm{m}^{-2}$. The drought and control field experiments were adjacent in each location. Previous analyses showed that the soil of Algerian experimental fields had 23\% clay, 33\% silt, $42 \%$ sand, and $2 \%$ organic matter. The Spanish field of 2016 was sandy-loam with $\mathrm{pH}=5.9$, organic matter $6.5 \%$, and $\mathrm{P}, \mathrm{K}^{+}$and $\mathrm{Mg}^{2+} 16,248$, and $124 \mathrm{mg} \mathrm{kg}^{-1}$ respectively. In 2017, the Spanish field was sandy-loam with $\mathrm{pH}=5.6$, organic matter $5.6 \%$, and $\mathrm{P}, \mathrm{K}^{+}$, and $\mathrm{Mg}^{2+} 128,220$, and $60 \mathrm{mg} \mathrm{kg}^{-1}$, respectively. Previous crop in all cases was maize and fertilization followed the recommendations of the respective agricultural services for each environment.

Eleven populations representing the geographic distribution of that collection were chosen for analyses of nutrients (Table 1), whereas 6 populations representing the diverse response to drought stress [20] were chosen for saccharification analyses. 
Table 1. Nutritive value ${ }^{1}$ (\%) of eleven Algerian maize populations and one Spanish check.

\begin{tabular}{ccccc}
\hline Population & Starch & Ash & Lipids & Proteins \\
\hline EPS13(FR)C3 & $76.82 \mathrm{c}$ & $1.97 \mathrm{ab}$ & $6.23 \mathrm{a}$ & $14.98 \mathrm{a}$ \\
PI527465 & $78.71 \mathrm{a}$ & $1.56 \mathrm{~b}$ & $6.12 \mathrm{a}$ & $13.61 \mathrm{a}$ \\
PI527467 & $77.83 \mathrm{abc}$ & $1.62 \mathrm{~b}$ & $5.95 \mathrm{a}$ & $14.61 \mathrm{a}$ \\
PI527469 & $77.04 \mathrm{abc}$ & $1.78 \mathrm{ab}$ & $6.48 \mathrm{a}$ & $14.70 \mathrm{a}$ \\
PI527470 & $77.91 \mathrm{ab}$ & $1.66 \mathrm{~b}$ & $6.01 \mathrm{a}$ & $14.42 \mathrm{a}$ \\
PI527472 & $77.38 \mathrm{abc}$ & $1.76 \mathrm{ab}$ & $6.24 \mathrm{a}$ & $14.62 \mathrm{a}$ \\
PI527473 & $77.31 \mathrm{bc}$ & $1.80 \mathrm{ab}$ & $6.58 \mathrm{a}$ & $14.31 \mathrm{a}$ \\
PI527474 & $77.20 \mathrm{abc}$ & $1.71 \mathrm{ab}$ & $6.27 \mathrm{a}$ & $14.82 \mathrm{a}$ \\
PI527475 & $76.56 \mathrm{bc}$ & $1.73 \mathrm{ab}$ & $6.68 \mathrm{a}$ & $15.02 \mathrm{a}$ \\
PI527478 & $76.96 \mathrm{abc}$ & $2.17 \mathrm{a}$ & $5.81 \mathrm{a}$ & $15.06 \mathrm{a}$ \\
PI542683 & $75.77 \mathrm{bc}$ & $1.80 \mathrm{ab}$ & $6.38 \mathrm{a}$ & $16.06 \mathrm{a}$ \\
PI542689 & $78.41 \mathrm{abc}$ & $1.62 \mathrm{~b}$ & $5.80 \mathrm{a}$ & $14.17 \mathrm{a}$ \\
\hline
\end{tabular}

${ }^{1}$ Means followed by the same letter within the same column were not significantly different, according to the LSD method at $p=0.05$.

These populations were sown the 26th of April 2016 at Algiers $\left(36^{\circ} 47^{\prime} \mathrm{N}, 2^{\circ} 03^{\prime} \mathrm{E}\right.$, altitude $32 \mathrm{~m}$ a.s.l.), a sub-humid region of the north of Algeria with $690 \mathrm{~mm}$ of annual rainfall, under control and drought conditions. Control blocks received $600 \mathrm{~mm}$ from sowing to post-flowering, while only $200 \mathrm{~mm}$ were applied under drought conditions. Algerian trials were harvested at the end of August. For checking adaptation to temperate conditions, a second trial was sown in Pontevedra (Latitude $42.40^{\circ} \mathrm{N}$ and Longitude $8.63^{\circ} \mathrm{W}$ ) the 4 th of May 2016 under rainfall conditions, and a third one the 23rd of May 2017 in Xinzo de Limia (Latitude $42.07^{\circ} \mathrm{N}$ and Longitude $7.73^{\circ} \mathrm{W}$ ) in the province of Ourense under control and drought (without irrigation) conditions. Spanish trials were harvested at the beginning of October. Grain samples from the original seed were used for analyzing nutritive composition on starch, proteins, lipids, and ash in the Laboratorio Agrario e Fitopatolóxico de Galicia following the official methods of the Spanish administration [21,22] (BOE 17 February 2000; BOE 2 March 1995).

Saccharification analyses were carried out using samples obtained under both drought and control conditions in 2017 from Xinzo de Limia field trial. At harvest time, five to eight plants were collected, ears were removed and the plant stover sample was chopped, pre-dried at $35^{\circ} \mathrm{C}$ in a forced air camera, and then dried at $60^{\circ} \mathrm{C}$ in a stove. Finally, dry stover samples from each plot were grounded in a Wiley mill with a $0.75 \mathrm{~mm}$ screen. Saccharification assays were performed as described in Gomez et al. [23]. Briefly, ground material was weighed into 96-well plates, each well contained $4 \mathrm{mg}$ of each sample either as four replicates; and processed using a high-throughput automated system (Tecan): samples were pre-treated with $0.5 \mathrm{M} \mathrm{NaOH}$ at $90^{\circ} \mathrm{C}$ for $30 \mathrm{~min}$, washed four times with $500 \mu \mathrm{L}$ sodium acetate buffer and finally subjected to enzymatic digestion (Celluclast 2, $7 \mathrm{FPU} / \mathrm{g}$ ) at $50{ }^{\circ} \mathrm{C}$ for $9 \mathrm{~h}$. The amount of released sugars was assessed against a glucose standard curve using the 3-methyl-2-benzothiazolinone hydrozone method. Saccharification potential was obtained for the whole plant without ear samples. Saccharification yield was obtained by multiplying dry biomass per plot by saccharification potential.

Analyses of variance were performed for each trait, being the sources of variation environments, treatments (well-watered and drought stress), populations, repetitions, and their interactions. Treatments, populations, and the treatment $\times$ population interaction were considered fixed effects while any other effect or interaction was considered random. Mean comparisons were made with the LSD method at $p$ value $=0.05$. All analyses were carried out with the statistical program SAS [24].

In order to investigate the possible effects of grain nutrients and agronomic traits on saccharification potential and saccharification yield, multiple regression analyses were made with saccharification potential and saccharification yield under drought and control conditions, as dependent variables, and the agronomic traits published by Maafi et al. [20] and grain nutrients, individually, by using the Proc Reg procedure of SAS [24] with a stepwise method ( $p$ value $=0.15$ ). Furthermore, the possible effects of nutrients on plant development were also assessed by performing multiple regression analyses 
with grain nutrients as independent variables and agronomic traits from all the environments as dependent variables.

\section{Results}

\subsection{Identifying Promising Algerian Populations in Relation to Grain Nutritional Composition}

Differences among maize populations were significant for starch and ash, but were not significant for lipids and proteins. Starch was lowest (76.82\%) for EPS13(FR)C3 and highest (78.71\%) for PI527465, followed by PI527470. Ash was lowest for PI527465, PI527467, and PI542689, and highest (2.17\%) for PI527478. Proteins varied from 13.61 for PI527465 to $16.06 \%$ for PI542683, and the value of the Spanish check EPS13(FR)C3 was $14.98 \%$. For lipids, the variation was between 5.80 , for PI542689, and $6.68 \%$ for PI527475. The Spanish check had a lipid content of $6.23 \%$.

\subsection{Identifying a Saccharification Use of the Stover under Stressed Conditions}

Drought and control conditions were not significantly different for saccharification potential, but varieties were significantly different for saccharification potential under drought conditions (Table 2). Under drought stress, saccharification potential was higher for the Spanish check EPS13(FR)C3 than for the Algerian populations PI527473 and PI527467, and for PI542683 than for PI527467. PI542683 had also high grain yield under drought conditions [20]. The two populations with lowest saccharification potential, PI527467 and PI527473, had high grain yield and PI527467 had also high early vigor and grain and biomass yield under drought conditions. PI542685 had only a reduction of $4 \%$ from control to drought conditions, indicating that this population was not sensibly affected by drought for saccharification potential.

Table 2. Saccharification ${ }^{1}$ in six Algerian maize populations and two Spanish checks under drought and control conditions.

\begin{tabular}{|c|c|c|c|c|}
\hline \multirow[b]{2}{*}{ Population } & \multicolumn{2}{|c|}{ Control Conditions } & \multicolumn{2}{|c|}{ Drought Conditions } \\
\hline & $\begin{array}{c}\text { Per Unit Dry } \\
\text { Matter (nmol } \\
\left.\text { Sugar } \mathrm{mg}^{-1} \mathrm{~h}^{-1}\right)\end{array}$ & $\begin{array}{l}\text { Yield (mmol Sugar } \\
\left.\qquad \mathbf{h a}^{-1} h^{-1}\right)\end{array}$ & $\begin{array}{c}\text { Per Unit Dry } \\
\text { Matter (nmol } \\
\left.\text { Sugar } \mathrm{mg}^{-1} \mathrm{~h}^{-1}\right)\end{array}$ & $\begin{array}{l}\text { Yield (mmol Sugar } \\
\left.\qquad h^{-1} h^{-1}\right)\end{array}$ \\
\hline EPS13(FR)C3 & $78.46 \mathrm{a}$ & $372.3 \mathrm{bc}$ & $89.64 \mathrm{a}$ & $359.5 \mathrm{a}$ \\
\hline PI542683 & $75.91 \mathrm{a}$ & $464.7 \mathrm{bc}$ & $85.75 \mathrm{ab}$ & $302.3 \mathrm{ab}$ \\
\hline PI542685 & $86.73 \mathrm{a}$ & $1025.6 \mathrm{a}$ & $83.08 \mathrm{ab}$ & $237.6 \mathrm{ab}$ \\
\hline EPS14FRC3 & $69.56 \mathrm{a}$ & $282.8 \mathrm{c}$ & $80.81 \mathrm{abc}$ & $313.4 \mathrm{ab}$ \\
\hline PI527472 & $80.76 \mathrm{a}$ & $470.6 \mathrm{bc}$ & $77.45 \mathrm{abc}$ & $303.1 \mathrm{ab}$ \\
\hline PI542684 & $68.45 \mathrm{a}$ & $609.4 \mathrm{~b}$ & $77.28 \mathrm{abc}$ & $310.2 \mathrm{ab}$ \\
\hline PI527473 & $88.09 \mathrm{a}$ & $318.0 \mathrm{bc}$ & $72.57 \mathrm{bc}$ & $167.8 \mathrm{~b}$ \\
\hline PI527467 & $79.13 \mathrm{a}$ & $419.8 \mathrm{bc}$ & $65.64 \mathrm{c}$ & $173.9 \mathrm{~b}$ \\
\hline
\end{tabular}

${ }^{1}$ Means followed by the same letter within the same column were not significantly different, according to the LSD method at $p=0.05$.

Saccharification yield was significantly lower (42.6\%) under drought (271.0 mmol sugar ha $\left.{ }^{-1} \mathrm{~h}^{-1}\right)$ than under control ( $472.4 \mathrm{mmol}$ sugar ha $\left.\mathrm{h}^{-1} \mathrm{~h}^{-1}\right)$ conditions, and there was a significant population $\times$ environment rank interaction. All populations except the check from dry Spain [EPS14(FR)C3] reduced saccharification yield from control to drought conditions. The reduction of saccharification yield was lowest for EPS13(FR)C3 (3.4\%) and highest for PI542685 (76.8\%). The northern Spanish check EPS13(FR)C3 had the highest saccharification yield under drought conditions, though several populations were not significantly different, particularly PI542685 and PI542683. Therefore, the population PI542685 could be a promising material in relation to bioethanol use and, as we previously mentioned, performs nicely in control and stresses conditions. 


\subsection{Effects of Agronomic Traits and Grain Nutrients on Saccharification}

Multiple regression analyses with the data from Xinzo de Limia in 2017 showed that none of the agronomic traits has significant effect on saccharification potential under control conditions, while under drought conditions biomass moisture had a negative effect, being $\mathbf{R}^{2}=0.81(p=0.0989)$. Concerning saccharification yield, under control conditions, the model for agronomic traits was significant: Saccharification yield $=-132.82+92.03 \times$ Dry biomass, being $R^{2}=0.89(p=0.0004)$ for dry biomass; and under drought conditions ear height had a positive effect $\left(R^{2}=0.24(p=0.0559)\right)$, and ears per plant a negative effect $\left[R^{2}=0.76(p=0.1271)\right]$. The inconsistency of the effects under control and drought conditions might be due to the weaknesses of the effects. Nevertheless, the results show that most agronomic traits had no significant effects on saccharification potential; except for the negative effect of biomass moisture under drought conditions.

Concerning the effects of grain nutrients, multiple regression analyses showed that the saccharification potential under control conditions was positively affected by grain lipids $\left[R^{2}=0.37\right.$ $(p=0.0541)]$, and negatively by proteins $\left[R^{2}=0.58(p=0.1330)\right]$. Under drought conditions, the model for saccharification potential was significant: Saccharification potential $=-125.26+79.49 \times$ Ash + $6.80 \times$ Proteins, being $\mathbf{R}^{2}=0.80(p=0.0410)$ for ash and $\mathbf{R}^{2}=0.17(p=0.0646)$ for proteins. In the multiple regression analyses for saccharification yield under control conditions, grain nutrients had no significant effects; and under drought conditions, grain ash had a positive effect, being $\mathrm{R}^{2}=0.55$ $(p=0.1493)$.

\subsection{Effects of Grain Nutrients on Plant Development}

The regression analyses for investigating possible effects of grain nutrients on plant development in all the environments pointed out the following significant models:

i. For early vigor under drought stress: Early vigor $=31.15-0.39 \times$ Starch, $\mathbf{R}^{2}=0.33(p=0.0491)$.

ii. For pollen shedding under control conditions: Pollen shedding $=61.10-17.26 \times$ Ash $-3.88 \times$ Lipids $+4.12 \times$ Proteins, $\mathbf{R}^{2}=0.27(p=0.0875)$ for ash, $0.32(p=0.0284)$ for proteins; and 0.11 $(p=0.1243)$ for lipids.

iii. For plant height under control conditions: Plant height $=636.75-7.00 \times$ Starch, $\mathrm{R}^{2}=0.34$ $(p=0.0468)$; and plant height under drought stress: Plant height $=878.82-11.29 \times$ Starch, $\mathrm{R}^{2}=0.65(p=0.0016)$.

iv. For ear height under control conditions: Ear height $=279.20-4.52 \times$ Starch $-60.08 \times$ Ash + $15.11 \times$ Proteins, $\mathbf{R}^{2}=0.34(p=0.0450)$ for proteins, $0.33(p=0.0142)$ for ash; and $0.08(p=0.1435)$ for starch; and ear height under drought stress: Ear height $=569.31-7.63 \times$ Starch, $R^{2}=0.58$ $(p=0.0041)$.

v. For grain yield under drought stress: Grain yield $=-2.81+0.79 \times$ Lipids, $R^{2}=0.34(p=0.0479)$.

vi. For grain moisture under control conditions: Grain moisture $=27.65-8.23 \times$ Ash, $R^{2}=0.40$ $(p=0.0277)$.

Summarizing, grain starch has significant negative effects on early vigor and plant height under drought and control conditions. Ash has significant negative effects on days to pollen, ear height, and grain moisture under control conditions. Lipids had significant positive effects on grain yield under drought stress. Finally, proteins had significant positive effect ear height under control conditions.

\section{Discussion}

Differences among maize populations were significant for starch and ash. Nutrients' values were close to the reported mean starch content for maize [8,25]. Besides having high starch content, PI527470 was drought tolerant based on grain yield [20]. Ash values were also close to the reported mean ash content for maize [8,25]. PI527467 had also high early vigor and grain and biomass yield under drought conditions [20], and PI527478 was drought tolerant based on grain and biomass yield, plant 
height, and biomass moisture. The differences between mean nutrient percentage in our study and the mean values reported by Inglett [8] could be explained by the lower grain yield of these populations compared to cultivated varieties. Protein values were higher than the reported mean protein content for maize [8,25]. PI527465 was not outstanding for drought tolerance [20], while PI542683 had high grain yield under drought conditions [20]. Most of the lipid values were also higher than the reported mean lipid content for maize [8,25]. PI542689 was not selected as drought tolerant, while PI527475 had tall plants and low biomass moisture under drought conditions [20].

Drought had no significant effect on saccharification potential. PI542683 had also high grain yield under drought conditions [20]. The two populations with lowest saccharification potential had high grain yield and PI527467 had also high early vigor and grain and biomass yield under drought conditions. PI542685 was not sensibly affected by drought for saccharification potential.

The effectiveness of the saccharification process relies on the accessibility of the fermentable sugars by the hydrolytic enzymes, which is determined by the degree of lignification and cell wall crosslinking mediated by hydroxycinnamates [11]. Besides the effects on the agronomic performance of the crop as could be the negative impact in total dry biomass; drought stress also provokes changes in cell wall composition [26,27], hence, affecting total saccharification efficiency. These changes in cell wall performance were previously related to increases or decreases of cell wall polysaccharides and lignin [28-32].

The effects of drought upon cell wall behavior depend on the crop, tissue under study, or the method used to obtain either the cell walls biochemical composition or its saccharification potential, as for example, one particular feedstock pre-treatment. Emerson et al. [30] quantified the drought effect on corn stover obtaining an increase in extractable components and a decrease in cellulose, hemicellulose, esterified $p$-coumaric acid content and lignin that was correlated with greater degradability. Similarly, van der Weijde et al. [32] observed in miscanthus reductions in cellulose and cell wall content, and an increase in hemicellulosic polysaccharides, and reported improvements on sugar release efficiency. Even though cell walls with these characteristics could be presented as a strategy to improve sugar release, the effect of drought on dry biomass affects the total saccharification yield requiring a greater amount of dry biomass to produce the same bioethanol as in control conditions [30].

The saccharification potential values found for these Algerian varieties were higher than previous results shown for temperate varieties [33]. PI542685 had a low reduction of saccharification under drought conditions and was considered drought-tolerant based on biomass production [20]. Saccharification yield was lower under drought than under control conditions, and there was a significant population $\times$ environment rank interaction. Most populations reduced saccharification yield from control to drought conditions, and the reduction was highest for PI542685, probably due to the limited adaptation of this last population [20]. The population PI542685 was considered a promising material in relation to bioethanol production and, as we previously mentioned, performed nicely in control and stresses conditions.

Even though the significance of the effects was small, the regression analyses showed that saccharification yield was affected positively by dry biomass under control conditions, whereas saccharification potential was significantly affected by grain ash and proteins under drought stress. In relation to the first significant effect, it makes sense that a higher dry matter content was related to saccharification yield taking into account that as dry matter increased, more cellulose material was available, and thereby more sugars were potentially extractable.

Concerning the effects of nutrients in agronomic performance, grain starch had significant negative effects on early vigor and plant height under drought and control conditions. Ash had significant negative effects on days to pollen, ear height, and grain moisture under control conditions. Lipids had significant positive effects on grain yield under drought stress. Finally, proteins had significant positive effect ear height under control conditions.

Altogether, there was significant diversity among Algerian populations for nutritive value and saccharification potential or yield, as expected based on previous studies about phenotypic and 
genotypic diversity $[4,18,19]$. The Algerian populations PI527465 and PI542689 had high starch and low ash. PI527469 and PI527474 had a balanced nutritional value. PI527475 and PI542683 had low starch and moderately high ash. Furthermore, PI542683 had as well high saccharification potential under drought conditions. In addition, as previously mentioned, the population PI542685 was a promising material for bioethanol production under stress conditions.

Most agronomic traits had no significant effects on saccharification; except for dry biomass, which increased, as expected, the saccharification yield. Furthermore, grain nutrients affected saccharification, though the only significant effect was for grain ash under drought stress. The effects of grain nutrients on agronomic traits indicated that increasing grain starch reduced agronomic performance. Increasing grain ash improved earliness at flowering and reduced ear height. Finally, grain lipids also improved grain yield under drought conditions.

\section{Conclusions}

From the present characterization, we concluded that (i) PI527465 and PI542689 had high energetic value, and PI527469 and PI527474 had balanced nutritional value, (ii) in addition to high nutritional value, the drought-tolerant population PI542683 had high saccharification under drought conditions, (iii) most agronomic traits had no significant effects on saccharification, (iv) some grain nutrients affected saccharification and agronomic performance, and (v) improving nutritive value of grain and saccharification of stover, while maintaining agronomic performance, was considered feasible, attending to the weak interactions between them.

Author Contributions: A.L.-M. has carried out the saccharification analyses and participated in the Spanish field trials and the analyses; A.D. has carried out the field trials in Algeria; L.G. has organized and supervised the saccharification study; R.S. has participated in the experimental design and the saccharification analyses; P.R. has carried out the trials in Spain, designed the experiment and made the analyses. All authors have read and agreed to the published version of the manuscript.

Funding: This work was financed by the Spanish Ministerio de Innovación y Universidades (MCIU), the Agencia Estatal de Investigación (AEI) and the European Fund for Regional Development (FEDER), UE (project code AGL2016-77628-R and RTI2018-096776-B-C22), and the École Nationale Supérieure Agronomique (Algeria).

Acknowledgments: Seed from Algerian populations was provided by the North Central Regional Plant Introduction Station of the USA. The nutritive analyses were carried out by Jaime Paz Fernández (Director of the Laboratorio Agrario e Fitopatolóxico de Galicia, Xunta de Galicia). The analyses of saccharification were carried out in the Centre for Novel Agricultural Products in University of York.

Conflicts of Interest: The authors declare no conflict of interest.

\section{References}

1. Choudhary, M.; Singh, A.; Gupta, M.; Rakshit, S. Enabling technologies for utilization of maize as a bioenergy feedstock. Biofuels Bioprod. Biorefining 2019, 14, 402-416. [CrossRef]

2. Fisher, M.; Tsedeke, A.Y.; Lunduka, R.W.; Asnake, W.; Alemayehu, Y.; Madulu, R.B. Drought tolerant maize for farmer adaptation to drought in sub-Saharan Africa: Determinants of adoption in eastern and southern Africa. Clim. Chang. 2015, 133, 283-299. [CrossRef]

3. Chen, J.P.; Xu, W.W.; Velten, J.; Xin, Z.G.; Stout, J. Characterization of maize inbred lines for drought and heat tolerance. J. Soil Water Conserv. 2012, 67, 354-364. [CrossRef]

4. Djemel, A.; Revilla, P.; Hanifi-Mekliche, L.; Malvar, R.A.; Álvarez, A.; Khelifi, L. Maize (Zea mays L.) from the Saharan oasis: Adaptation to temperate areas and agronomic performance. Genet. Res. Crop Evol. 2012, 59, 1493-1504. [CrossRef]

5. Djemel, A.; Cherchali, Z.F.; Benchikh, L.H.M.; Malvar, R.A.; Revilla, P. Assessment of drought tolerance among Algerian maize populations from oases of the Saharan. Euphytica 2018, 214, 149. [CrossRef]

6. Djemel, A.; Álvarez-Iglesias, L.; Santiago, R.; Malvar, R.A.; Pedrol, N.; Revilla, P. Algerian maize populations from the Sahara Desert as potential sources of drought tolerance. Acta Physiol. Plant. 2019, 41, 12. [CrossRef]

7. Sarwar, M.H.; Sarwar, M.F.; Sarwar, M.; Qadri, N.A.; Moghal, S. The importance of cereals (Poaceae: Gramineae) nutrition in human health: A review. J. Cereals Oilseeds 2013, 4, 32-35. [CrossRef] 
8. Inglett, G.E. Kernel structure, composition, and quality. In Corn: Culture, Processing, Products; AviPublishing: Westport, CT, USA, 1970; pp. 123-137.

9. Brown, W.L.; Bressani, R.; Glover, D.V.; Hallauer, A.R.; Johnson, V.A.; Qualset, C.O. Quality-Protein Maize: Report of an Ad Hoc Panel of the Advisory Committee on Technology Innovation. Board on Science and Technology for International Development, National Research Council, in Cooperation with the Board on Agriculture, National Research Council; National Academy Press: Washington, DC, USA, 1988.

10. Mertz, E.T. Nutritive value of corn and its products. In Corn: Culture, Processing, Products; Inglett, G.E., Ed.; AviPublishing: Westport, CT, USA, 1970; pp. 350-359.

11. Dhugga, K.S. Maize biomass yield and composition for biofuels. Crop Sci. 2007, 47, 2211-2227. [CrossRef]

12. Vermerris, W.; Saballos, A.; Ejeta, G.; Mosier, N.S.; Ladisch, M.R.; Carpita, N.C. Molecular breeding to enhance ethanol production from corn and sorghum Stover. Crop Sci. 2007, 47, 142-153. [CrossRef]

13. Lorenz, A.J.; Coors, J.G.; De Leon, N.; Wolfrum, E.J.; Hames, B.R.; Sluiter, A.D.; Weimer, P.J. Characterization, genetic variation, and combining ability of maize traits relevant to the production of cellulosic ethanol. Crop Sci. 2009, 49, 85-98. [CrossRef]

14. Kadam, K.L.; McMillan, J.D. Availability of corn stover as a sustainable feedstock for bioethanol production. Bioresour. Technol. 2003, 88, 17-25. [CrossRef]

15. Graham, R.L.; Nelson, R.; Sheehan, J.; Perlack, R.D.; Wright, L.L. Current and potential U.S. corn stover supplies. Agron. J. 2007, 99, 1-11. [CrossRef]

16. Tenenbaum, D.J. Food vs. fuel: Diversion of crops could cause more hunger. Environ. Health Perspect. 2008, 116, A254-A257. [CrossRef] [PubMed]

17. Wang, M.; Han, J.; Dunn, J.B.; Cai, H.; Elgowainy, A. Well-to-wheels energy use and greenhouse gas emissions of ethanol from corn, sugarcane and cellulosic biomass for US use. Environ. Res. Lett. 2012, 7, 45905. [CrossRef]

18. Aci, M.M.; Revilla, P.; Morsli, A.; Djemel, A.; Belalia, N.; Kadri, Y.; Khelifi-Saloui, M.; Ordás, B.; Khelifi, L. Genetic diversity in Algerian maize (Zea mays L.) landraces using SSR markers. Maydica 2013, 58, 304-310.

19. Cherchali, F.Z.; Ordás, B.; Revilla, P.; Pedrol, N.; Djemel, A. Heterotic Patterns among Algerian, US Corn Belt, and European Flint Maize Populations under the Mediterranean Conditions of North Africa. Crop Sci. 2018, 58, 2422-2432. [CrossRef]

20. Maafi, O.; Djemel, A.; Álvarez-Iglesias, L.; Malvar, R.A.; Revilla, P. Adaptation assessment of drought tolerant maize populations from the Sahara in both shores of the Mediterranean Sea. Euphytica 2020. under revision.

21. BOE 17/02/2000. ORDEN de 16 de Febrero de 2000 por la que se Modifica el Anexo del Real Decreto2257/1994, de 25 de Noviembre, por el que se Aprueban los Métodos Oficiales de Análisis de Piensos o Alimentos para Animales y sus Primeras Materias y el Real Decreto 1999/1995, de 7 de Diciembre, Relativo a los Alimentos Para Animales Destinados a Objetivos de Nutrición Específicos; State Agency of Official State Gazette: Madrid, Spain, 2000.

22. BOE 02/03/1995. Real Decreto2257/1994, de 25 de Noviembre, por el que se Aprueban los Métodos Oficiales de Análisis de Piensos o Alimentos para Animales y sus Primeras Materias; State Agency of Official State Gazette: Madrid, Spain, 1995.

23. Gomez, L.D.; Whitehead, C.; Barakate, A.; Halpin, C.; McQueen-Mason, S.J. Auto-mated saccharification assay for determination of digestibility in plant materials. Biotechnol. Biofuel 2010, 3, 23. [CrossRef]

24. SAS Institute Inc. SAS/STATß9.2 User's Guide; SAS Institute Inc.: Cary, NC, USA, 2008.

25. Blandino, M.; Mancini, M.C.; Alessandro, P.; Luca, R.; Francesca, V.; Amedeo, R. Determination of maize kernel hardness: Comparison of different laboratory tests to predict dry-milling performance. J. Sci. Food Agric. 2010, 90, 1870-1878. [CrossRef]

26. Moore, J.P.; Vicré-Gibouin, M.; Farrant, J.M.; Driouich, A. Adaptations of higher plant cell walls to water loss: Drought vs. desiccation. Physiol. Plant. 2008, 134, 237-245. [CrossRef]

27. Pauly, M.; Keegstra, K. Plant cell wall polymers as precursors for biofuels. Curr. Opin. Plant Biol. 2010, 13, 304-311. [CrossRef] [PubMed]

28. Hu, Y.; Li, W.C.; Xu, Y.Q.; Li, G.J.; Liao, Y.; Fu, F.L. Differential expression of candidate genes for lignin biosynthesis under drought stress in maize leaves. J. Appl. Genet. 2009, 50, 213-223. [CrossRef] [PubMed]

29. Meibaum, B.; Riede, S.; Schröder, B.; Manderscheid, R.; Weigel, H.J.; Breves, G. Elevated $\mathrm{CO}_{2}$ and drought stress effects on the chemical composition of maize plants, their ruminal fermentation and microbial diversity in vitro. Arch. Anim. Nutr. 2012, 66, 473-489. [CrossRef] [PubMed] 
30. Emerson, R.; Hoover, A.; Ray, A.; Lacey, J.; Cortez, M.; Payne, C.; Karlen, D.; Birrell, S.; Laird, D.; Kallenbach, R.; et al. Drought effects on composition and yield for corn stover, mixed grasses, and Miscanthus as bioenergy feedstocks. Biofuels 2014, 5, 275-291. [CrossRef]

31. El Hage, F.; Legland, D.; Borrega, N.; Jacquemot, M.P.; Griveau, Y.; Coursol, S.; Mechin, V.; Reymond, M. Tissue lignification, cell wall p-coumaroylation and degradability of maize stems depend on water status. J. Agric. Food Chem. 2018, 66, 4800-4808. [CrossRef] [PubMed]

32. Van der Weijde, T.; Huxley, L.M.; Hawkins, S.; Sembiring, E.H.; Farrar, K.; Dolstra, O.; Visser, R.G.F.; Trindade, L.M. Impact of drought stress on growth and quality of miscanthus for biofuel production. GCB Bioenergy 2017, 9, 770-782. [CrossRef]

33. Barros-Rios, J.; Romani, A.; Peleteiro, S.; Garrote, G.; Ordás, B. Second-generation bioethanol of hydrothermally pretreated stover biomass from maize genotypes. Biomass Bioenergy 2016, 90, 42-49. [CrossRef]

(C) 2020 by the authors. Licensee MDPI, Basel, Switzerland. This article is an open access article distributed under the terms and conditions of the Creative Commons Attribution (CC BY) license (http://creativecommons.org/licenses/by/4.0/). 